UDK 78.082.1 Šostakovič: 78(497.4)

Anuša Volovšek

Oddelek za mentalno zdravje, Psihiatrična klinika Ljubljana

Clinical Department for Mental Health, Psychiatric Hospital Ljubljana

\title{
Recepcija Dmitrija Šostakoviča in njegove Prve simfonije na Slovenskem (1947-2001)*
}

\section{The Reception of Dmitry Shostakovich and His First Symphony in Slovenia (1947-2001)}

Ključne besede: Dmitrij Šostakovič, Prva simfonija, koncertni komentar, glasbena kritika, orkester Slovenske filharmonije

\section{PovZETEK}

Na osnovi glasbeno-analitičnih dognanj Šostakovičeve Prve simfonije in analize glasbeno-publicističnih tekstov sem opazovala družbeno recepcijo skladatelja in njegovega dela. $\mathrm{V}$ ta namen sem analizirala spremne besede koncertnih listov orkestra Slovenske filharmonije ter glasbene kritike, objavljene v dnevnem časopisju, v obdobju med letoma 1947 in 2001 . Vsa spoznanja izkazujejo dokaj površno razumevanje skladatelja in njegovega ustvarjanja. Mnogo je izrečenih sodb, ki omenjajo le posamezne "dele resnice", malo pa je takšnih, ki bi predstavljale bistvene elemente v skladateljevem delovanju - razumevanje mesta Šostakoviča in njegove Prve simfonije v zgodovini glasbe ter razumevanje skladateljevega glasbeno-kompozicijskega mišljenja oziroma razumevanje estetike časa in na njej osnovane skladateljeve poetike.
Keywords: Dmitry Shostakovich, First symphony, concert notes, music criticism, Slovenian Philharmonic Orchestra

\section{Summary}

On the basis of analytical results concerning Shostakovich's First Symphony and its relevant musical texts in periodicals, the public reception of the composer and his work was observed. For this purpose, concert programme notes of the Slovenian Philharmonic as well as music reviews in daily newspapers, published from 1947 to 2001, were analysed. All these "cognitions" reflect a rather superficial understanding of the composer and his musical creations. Many judgements mention only "partial truths", whereas only a few manage to present the essential elements of the composer's endeavours, i.e. to understand Shostakovich's place and that of his First Symphony in the history of music by getting to the heart of his compositional thinking, and thus detecting the aesthetics of time and their individual derivative - the composer's poetics.

\footnotetext{
* Vsebina prispevka je povzeta po diplomski nalogi, ki je nastala pod mentorstvom doc. dr. Matjaža Barba na Oddelku za muzikologijo Filozofske fakultete v Ljubljani. V prvem delu sem se ukvarjala z glasbeno analizo Šostakovičeve Prve simfonije. Ker pa mi je ta služila le kot podlaga za predstavitev družbene recepcije skladatelja in njegovega dela, je v prispevku ne predstavljam.
} 
Ustvarjanje Dmitrija Šostakoviča (1906-1975) je v zgodovino glasbe zarisalo globoko brazdo, ki s svojo kompleksno pojavnostjo zahteva tudi kompleksno opazovanje. Nenatančno poznavanje družbenih, glasbenih in glasbeno-estetskih premis časa ter nepozornost pri opazovanju njihovega medsebojnega vplivanja kaj hitro zamegli osnovne temelje razumevanja samega pojava.

Čas in prostor Šostakovičevega umetniškega delovanja pogojujeta izjemno specifičen ustvarjalni položaj. Družbene spremembe v Sovjetski zvezi po oktobrski revoluciji so posredno vplivale tudi na umetniške kategorije in znotraj teh tudi na glasbo. Ta je morala biti razumljiva in dostopna širokemu krogu poslušalcev; v svoji razumljivosti pa je morala izražati politično-ideološke in socialne momente ter biti usklajena s socialno in politično doktrino države. Takšne zahteve pa so zajele tudi del glasbeno-estetskih premis določenega časa in okolja. Pri opazovanju in analiziranju Šostakovičevih del je poleg poznavanja družbeno-političnih okoliščin in glasbeno-estetskih postavk časa potrebno slediti tudi skladateljevim individualnim umetniškim intencam in skladateljevi poetiki.

Vse zapisane misli in sodbe o glasbenem delu v določenem času in prostoru, ki se pojavljajo $\mathrm{v}$ različnih publicističnih objavah, skupno oblikujejo splošno družbeno mnenje o umetnini in določajo njeno družbeno vrednost. Torej lahko družbeno mnenje o umetnini opazujemo kot skupek različnih strokovnih avtorskih mnenj, katerih drugačnost ni toliko odvisna od subjektivno-avtorskega interpretativnega izbora, ampak od poznavanja glasbenega dela in preciznosti pri prilagajanju izbranih vsebin ciljnemu poslušalstvu.

Namen prispevka je predstavitev družbene recepcije Šostakoviča in njegove Prve simfonije na Slovenskem, kot jo je mogoče razbrati iz spremnih besed koncertnih komentarjev in glasbenih kritik koncertnih izvedb dela ter predstavitev izsledkov analize njihovih medsebojnih povezanosti, pogojenosti in ustreznosti. ${ }^{1}$ Prilagam tudi kronološko ureditev vseh izvedb Šostakovičevih del, ki jih je izvedel orkester Slovenske filharmonije med letoma 1947 in 2001 (priloge 1-6). Priloga 7 je sistematični prikaz števila vseh izvajanj posameznega skladateljevega dela $\mathrm{v}$ posameznih desetletjih in $\mathrm{v}$ celotnem omenjenem obdobju. Priloga 8 je urejena po isti metodi kot priloga 7 , le da pri tem niso upoštevane ponavljajoče se izvedbe skladateljevih del na posameznih turnejah. Če določeno delo ni bilo izvajano vsaj en mesec pred izvajanjem na turneji, so vse izvedbe v eni turneji obravnavane kot ena izvedba. Če pa je bila skladba izvedena neposredno pred odhodom na turnejo, izvedbe na turneji niso upoštevane.

V obdobju med letoma 1947 in 2001 je orkester Slovenske filharmonije Šostakovičevo Prvo simfonijo pogosto izvajal, če jo primerjamo s številom izvedb ostalih skladateljevih del. Bila je tudi del koncertnega programa petih koncertov gostovanja Slovenske filharmonije v Italiji leta 1955. Če ne upoštevamo gostovanj orkestra, jo je v številu izvajanj na Slovenskem prehitela le še Šostakovičeva Peta simfonija (priloga 8).

Kljub pogostemu izvajanju Prve simfonije pa je število koncertnih komentarjev in glasbenih kritik, ki bi omenjali skladatelja in njegovo delo, manjše. Kar nekajkrat sem namreč zasledila, da je kljub izvajanju Šostakovičevih del komentiranje le-teh izvzeto tako iz koncertnih komentarjev kot tudi iz kritik; v slednjih pa je zelo pogosto zaslediti tudi to, da je Prvi simfoniji namenjeno veliko manj besed kot ostalim delom komentiranega koncerta.

Dokaj majhno število besedil vsekakor delno omejuje vpogled $\mathrm{v}$ analitično tematiko. Na drugi strani pa morda zastavlja novo vprašanje: zakaj posamezni avtorji spremnnih

\footnotetext{
${ }^{1}$ Kot gradivo so mi služile spremne besede koncertnih listov orkestra Slovenske filharmonije in glasbene kritike koncertnih izvedb, objavljene v Slovenskem poročevalcu, Ljudski pravici, Delu in Dnevniku.
} 
besed koncertnih listov in glasbenih kritik niso vsakokrat komentirali Šostakovičevih del, ko so bila ta izvajana? Glede na obdobje, $v$ katerem je omenjeni pojav večkrat zaslediti, to je čas 50., 60. in 70. let, bi morda lahko sklepali, da poznavanje ter razumevanje Šostakoviča in njegove glasbe še ni bilo tolikšno, kot je danes, pa tudi v izvajalski praksi njegova dela še niso bila tako "ukoreninjena" kot danes. Morda posamezni avtorji niso želeli podajati posameznih sodb o skladatelju in njegovemu ustvarjanju oziroma so se temu izognili. To so le domneve, ki bi za svojo potrditev potrebovale nadaljnja opazovanja in argumentiranja.

Pri tem sem izpustila dejstvo, da oblike koncertnih komentarjev v omenjenem obdobju niso bile take kot danes, tipizirane skoraj v smislu obrazca: pri vsakem izvedenem delu koncertnega dogodka zapisati nekaj o skladatelju in nekaj o delu. V zgodnejših koncertnih listih namreč velikokrat zasledimo komentar le k eni od izvajanih skladb, prav tako pa so redki tudi podatki o skladatelju. Koncertni komentarji zgodnejšega obdobja (pribl. med letoma 1947 in 1970), v katerih so avtorji pisali o Šostakovičevi Prvi simfoniji, so analitično bolj izčrpni in v posameznih fragmentih kažejo na malenkost večje razumevanje dela kot koncertni komentarji kasnejšega obdobja, v katerem le-ti pričnejo postopoma dobivati analitično manj poglobljen in predvsem opisen značaj. Pri tem bi morda hipotetično lahko sklepala na to, da je postopno razvijajoči se nov tip koncertnega komentarja v obliki "obvezujočega obrazca" vplival na nujnost pisanja o delu, ki pa je verjetno posledično vplivala na pristop in zahtevnost $\mathrm{v}$ pisanju.

Težje pa je razčleniti dejstvo, zakaj je bilo Šostakovičevi Prvi simfoniji v glasbenih kritikah velikokrat namenjenega manj prostora kot ostalim delom, oziroma zakaj je prihajalo celo do izpuščanja besed o njeni koncertni izvedbi. Pri tem me omejuje še manjše število primerov kot pri koncertnih komentarjih, ki poleg tega ne izkazujejo posebnih značilnosti in zato tudi ne ponujajo možnosti sklepanja.

Dodaten problem, ki omejuje širši in objektivnejši vpogled v družbeno recepcijo Šostakoviča in njegovega ustvarjanja, so večkrat skoraj dobesedno ponavljajoči se koncertni komentarji. ${ }^{2}$ Redko namreč zasledimo, da bi isti avtor, ki je komentiral določeno število koncertnih izvedb Prve simfonije, napisal več različnih spremnih besed. Razumljivo je, da se interpretacija skladatelja in njegovega dela ne more spreminjati iz izvedbe $\mathrm{v}$ izvedbo, vseeno pa bi določena spremenljivost pri izbiri različnih podatkov lahko ponujala boljše razumevanje posameznih avtorskih sodb. V devetdesetih letih se število glasbenih piscev sicer poveča, vendar je večina spremnih besed zaupana le enemu, katerega komentarji pa se dosledno ponavljajo.

Zaradi nenehnega ponavljanja v celotnem obdobju, ki večinoma ni vključevalo tudi malenkostnih sprememb, so avtorske sodbe s svojo enkratno "podobo" in sporočilnostjo determinirale določen del tega obdobja, v katerem sta pisala ponavadi največ dva glasbena pisca. Pri tem nastopi nov problem. Avtorske misli, ki so zaradi nenehnega ponavljanja pridobile značaj "kanona" za določeno obdobje, lahko zaradi popolne nespremenljivosti, ki posledično ne dopušča širšega razumevanja, v primerjavi z mislimi drugih obdobij izzvenijo kot nasprotujoče in zato neresnične.

Poleg omenjenega je edini element, ki se spreminja v celotnem obravnavanem obdobju (1947-2001), interpretiranje medsebojnega odnosa skladatelja in družbenih razmer njegovega časa in prostora. Pred devetdesetimi leti sem misel o tem zasledila le dvakrat, v devetdesetih letih pa omenjena tema stopa vedno bolj v ospredje. Razlika je tudi v predstavljanju problematike. Spreminjanje slednje bi lahko razumeli kot postopen

\footnotetext{
2 Zaradi tega sem kot vir navedla le eno od ponavljajočih se spremnih besed koncertnih komentarjev $\mathrm{k}$ posameznim izvedbam Šostakovičeve Prve simfonije.
} 
razvoj v smeri vedno večje objektivnosti, kar pa zaradi tako majhnega števila besedil pred devetdesetimi leti ne moremo predstavljati kot absolutno resnico.

Izhajala sem iz dejstva, da je Šostakovičeva Prva simfonija delo, ki ga je potrebno opazovati v svojem času, kar posledično pomeni, da je potrebno biti pozoren na estetske premise tega časa ter na osnovi slednjih opazovati skladateljevo individualno poetiko.

Pri predstavljanju Šostakoviča različni avtorji največkrat primerjajo in povezujejo njegovo simfonično ustvarjanje s simfonično tradicijo devetnajstega stoletja oziroma ga omenjajo kot nadaljevalca Beethovnove tradicije. Poleg tega pa v devetdesetih letih močno izstopa sodba, da Šostakovič ni bil novotar. ${ }^{3}$ Pri tem je jasno, da zanemarjajo zgodovinski trenutek, zaradi katerega Šostakovič ni mogel nadaljevati simfonične tradicije, ki je bila v omenjenem obdobju prekinjena. S tem pa tudi zastirajo dejstvo, da je skladateljeva simfonija delo, ki ga je potrebno razumeti kot interakcijo prevzetega modela zvrsti in novega oblikovanja, kot posledico nove estetike. To domnevo pa še dodatno potrjuje omenjena sodba, ki Šostakoviču pripisuje "nenovotarstvo".

Enako velja za predstavitve Prve simfonije. Poleg tega, da zasledimo simfonijo označeno kot "pravzaprav tradicionalno" delo ${ }^{4}$, sodbo, ki ima enako izhodišče kot zgoraj omenjene misli, pa je skupno skoraj vsem avtorjem, da predstavljajo simfonijo kot "mladostno delo". Resda je delo mladostno, toda ne tako, kot ga interpretiajo posamezni glasbeni pisci. Najbolj skrajna oblika predstavitve je simfonija kot "šolsko delo"s nekateri avtorji pa opravičujejo posamezne "prevzete" in "tradicionalne" elemente s skladateljevo mladostjo.

V navajanju prevzetih elementov si avtorji niso enaki. Nekateri navajajo vpliv Stravinskega in Prokofjeva ali le enega od njiju, nekateri pa v skladateljevem delu opažajo elemente zahodnoevropske glasbe poznega devetnajstega stoletja. Enotni so tudi v tem, da je vsak element, ki ga je Šostakovič prevzel iz tradicije ali od svojih "starejših sodobnikov", potrebno interpretirati kot značilnost mladega ustvarjalca. Interpretacijam manjka celostna slika, ki bi jo lahko dobili, če bi vključili vse naštete podatke o prevzetih elementih in jih predstavili kot samoumeven dejavnik v kompozicijskem procesu, ki pa ni opažen le v skladateljevem zgodnjem delu, ampak tudi v njegovem nadaljnem ustvarjanju. Če pa se avtor odloči, da bo izpostavil določen podatek, torej del resnice, je to smiselno le v primeru, če je v njegovem nadaljevanju možno razbrati, zakaj je izbral prav ta podatek.

Avtorji glasbenih kritik, $\mathrm{z}$ izjemo enega ${ }^{6}$, se $\mathrm{v}$ umevanju zgodovinskega mesta simfonije in v prevzemanju tujih elementov v njej ne oddaljujejo od mišljenja avtorjev koncertnih komentarjev, pač pa to le potrjujejo. Vse omenjene sodbe dopolnjujejo še z mislimi o pravilnosti romantičnega izvajanja počasnih delov simfonije, kar spodbija kakršnokoli možnost, da bi bilo delo predstavljeno kot delo dvajsetega stoletja. Na to dejstvo je opozoril le en kritik, katerega pravilna sodba pa $v$ množici ostalih ostaja popolnoma zamegljena.

Pri obravnavanju tematskega gradiva simfonije sem izhajala iz analitičnih ugotovitev Šostakovičevega tematskega dela, kar pa me je privedlo tudi do nadaljnjih zaključkov o skladateljevemu simfoničnemu oblikovanju.

Teme kot "nosilke" Šostakovičevih glasbenih misli in specifičen način tematskega dela kot odraz njegovega glasbenega mišljenja gradijo individualen kompozicijski slog,

\footnotetext{
3 Monika Kartin: [komentar], v [Koncertni list za 8. modri abonmajski koncert SF, 17. in 18. 2. 1994].

${ }^{4}$ Monika Kartin: [komentar], v [Koncertni list za 8. modri abonmajski koncert SF, 8. in 9. 6. 2000].

5 D. [anilo] P.[okorn]: v [Simfonični koncertni list orkestra Slovenske filharmonije za 4. koncert rdečega abonmaja SF, 17. 2. 1964].

${ }^{6}$ R. [afael] Aljec: [kritika], v [Ljudska pravica, 15. 1. 1959].
} 
kar lahko razumemo kot dialektiko prevzetega iz tradicije in novega - individualne skladateljeve poetike, ki so jo vodile estetske predpostavke njegovega časa.

In če strnem glavne analitične ugotovitve, je eden osnovnih in zelo izraženih principov Šostakovičevega simfoničnega oblikovanja močna kontrastnost pri tematskem oblikovanju, preoblikovanju in prevrednotenju ter pri konfrontiranju tematskega gradiva $\mathrm{v}$ posameznih stavkih in med posameznimi stavki. Posledica takšnega oblikovanja pa je izrazito konfliktna simfonična dramaturgija, katero lahko opazujemo znotraj posameznih stavkov simfoničnega cikla, ki pa na osnovi tematske povezave gradijo večji simfonično-dramaturški kompleks.

Če opazujemo tematsko oblikovanje, ugotovimo, da je Šostakovič nekatere glasbene misli oblikoval iz dveh kontrastnih si tematskih gradiv. To je eden od elementov, ki je stopnjeval že sicer zelo "slikovito" in gestično zasnovane glasbene misli. Naslednja raven doseganja kontrasta je kontrastnost med posameznimi temami v svoji izhodiščni obliki, nadalje kontrastnost med izhodiščno obliko teme in njeno izrazno preoblikovano podobo, ki jo je skladatelj dosegal največkrat s spremembami dinamike, metruma, instrumentacije in intonacije posamezne teme. Nadaljnje kontraste pa je Šostakovič vzpostavljal z nenehnim zaporednim in simultanim konfrontiranjem različnih značajev različnih glasbenih misli, katerih spreminjanje v svojo končno podobo nastopi šele v četrtem, zadnjem stavku simfonije. Kontrast kot formotvorni element pa se izkaže tudi na ravni povezanosti stavkov simfonije. Tudi glasbeno-dramaturške gradnje posameznih stavkov si namreč medsebojno kontrastirajo, 'če jih opazujemo posamezno, a prav na osnovi teh kontrastov oblikujejo izrazito dinamiko dela. Ta je kljub svoji večstavčni obliki tako tematsko kot dramaturško nedeljiva celota.

Glasbeni pisci pa pri omenjanju tematskega gradiva simfonije ostajajo večinoma pri naštevanju in opisovanju značajev posameznih tem. Velikokrat pa brez razloga omenjajo le tematiko prvega stavka, kdaj tudi samo uvodno in prvo temo. Pri razčlenjevanju tematskega gradiva prvega stavka pa se zelo jasno izrazi problematika "kanonsko označenih obdobij", ki sem jo že izpostavila. Do 70. let je prevladovala sodba, da ima prvi stavek Šostakovičeve Prve simfonije tri teme ${ }^{7}$, pozneje, vse do 90 ., naj bi imel stavek dve temi ${ }^{8}, \mathrm{v}$ 90. letih pa poslušalec izve, da je celotna simfonija osnovana na eni sami glasbeni misli9.

Nobena od navedenih sodb ni popolnoma neresnična, če jo opazujemo izven interpretativnega konteksta, pa tudi popolnoma resnična ne. Razlikovanje med prvima dvema se je na osnovi različnih virov izkazalo kot rezultat individualnih argumentacij. Sodba 90. let pa med temi tremi izzveni najbolj neverjetno. Toda če sledimo Šostakovičevim principom oblikovanja Prve simfonije, ugotovimo, da ima avtorska misel v svojem ozadju latentno idejo tematske povezanosti celotnega dela. Izražena sodba pa je pretirana in zato neresnična. Pri tem se torej tudi izkaže, kako lahko navedeni podatek, ki sta mu odvzeta argumentacija in odgovarjajoči interpretativni kontekst, izgubi v "kategoriji resničnosti".

Avtorji, ki omenjajo tudi glasbene misli ostalih stavkov oziroma vseh štirih stavkov, pa s svojim interpretiranjem $v$ večini ne izkazujejo bistva Šostakovičevega simfoničnega oblikovanja. Nekajkrat je sicer zaslediti posamezne drobce v opažanju, kot so opozarjanje na reminiscenco določene teme oziroma na preoblikovanje uvodne teme prvega stavka. Toda iz slednjega je težko razbrati, zakaj je avtor zapisal takšen podatek, in če ga je že, zakaj ni svojih misli tudi v tej smeri nadaljeval in razvijal. Vsekakor pa je na osnovi

7 D. [anilo] P.[okorn]: v [Simfonični koncertni list orkestra Slovenske filharmonije za 4. koncert rdečega abonmaja SF, 17. 2. $1964]$.

${ }^{8}$ Roman Leskovic: $\mathrm{v}$ [Simfonični koncertni list orkestra Slovenske filharmonije za simfonični koncert SF, 11. 11. 1974].

9 Monika Kartin: [komentar], v [Koncertni list za 8. modri abonmajski koncert SF, 17. in 18. 2. 1994]. 
tega težko potrditi, da je posamezni avtor morda le razumel skladateljevo ustvarjanje, a se zaradi "neznanih" razlogov ni posvečal tolikšni natančnosti pri analitični predstavitvi.

S svojimi zadnjimi mislimi verjetno ponujam največjo možnost očitka. V uvodu sem namreč opredelila ciljno publiko koncertnih komentarjev in glasbenih kritik ter predpostavila problematiko: kako zadostiti potrebam jasnosti in ne prevelike strokovnosti, obenem pa ohranjati distanco do tolikšnega posploševanja, katerega posledica je lahko dejanska strokovna vprašljivost? Toda pri opazovanju in komentiranju posameznih avtorskih sodb se morda marsikdaj zazdi, da sem morda pozabila na namen glasbeno-publicističnih tekstov.

Vendar pa sem želela prikazati prav nasprotno. Opazovanje in kritiko glasbeno-publicističnih tekstov s poskusom argumentiranja razumem kot nujno na poti $\mathrm{k}$ strokovni presoji. Vsekakor pa je potrebno vse izsledke "vrniti v naravno okolje" in opazovati njihovo vrednost znotraj njihove funkcije.

Razumljivo je, da namen predstavitve umetnine in njegovega avtorja ni obširno predstavljanje posameznih problematik. Zelo pomembno pa je, da avtor določene podatke izbira na takšen način, pri katerem je lažja možnost poenostavitve, če je ta pač potrebna.

Največ napak $\mathrm{v}$ predstavljanju je namreč rezultat nizanja posameznih podatkov, katerim avtorji odvzemajo odgovarjajoči kontekst, ob tem pa jih predstavljajo kot dejstva. Poznavalec Šostakoviča in njegovega ustvarjanja lahko namreč v večini zapisanih misli, ki sem jih obravnavala, predpostavlja njihova ozadja. Tega pa vsekakor ne moremo pričakovati od poslušalca "ljubitelja". Ta je večinoma nagnjen k sprejemanju podatkov v podani obliki.

Takšnim napakam v podajanju in izbiri se lahko glasbeni pisec izogne večinoma le, če je osnova njegove predstavitve lastno znanje in razumevanje. Verjetno je najpogostejši vzrok neprimernega predstavljanja tudi nepopolno poznavanje konkretnih problematik pri prevzemanju in prirejanju avtorskih misli. Slednje potrjujejo tudi posamezni pisci, ki apriorno navajajo posamezne trditve, tako da izzvenijo popolnoma neverjetno, pri tem pa ne čutijo potrebe po pojasnilu ali po navedbi avtorja ideje in predstavitvi le-te kot "ene od več možnih interpretacij".

Mnenje, da je vzrok nepravilnemu predstavljanju nepopolno poznavanje, še bolj jasno potrjuje primer glasbene kritike. Pisanje takšnih kritik, ki vključujejo oceno izvedbe, namreč ni tako obremenjeno s posploševanjem in prirejanjem. In če slednje ne more biti razlog nepravilni slogovni opredelitvi, ki jo je razbrati iz ocene slogovne interpretacije, je razlog lahko verjetno iskati le v slabšem poznavanju oziroma "nerodno" izbranem izrazu.

V obravnavanem obdobju nisem ugotovila kakšnega bistvenega razvoja niti nazadovanja $v$ razumevanju in predstavljanju omenjenih problematik. Opazila pa sem nekaj primerov, ki jih je potrebno opazovati kot odraz svojega časa. Pri tem izstopa predvsem nekaj primerov glasbene kritike, kar pa je pogojeno $\mathrm{z}$ drugačnim načinom predstavljanja in zato tudi malenkost drugačnim spektrom strokovnega izrazja. ${ }^{10}$ To v posameznih primerih, $v$ primerjavi $z$ današnjim časom, izkazuje delno nedodelanost. Tako na primer avtor v petdesetih letih piše o "privržencih moderne" misli razbrati, da pri tem ne misli na termin moderna, kot ga razumemo danes. Zato je $\mathrm{v}$ takšnem primeru potrebno, da skušamo razumeti, kaj je določen izraz posameznemu avtorju pomenil, pa tudi čas, $v$ katerem so njegove misli nastale.

Pri tem je zanimivo, da je edini primer kritike, $v$ kateri je avtor po mojem mnenju pokazal popolnoma pravilno razumevanje mesta Šostakovičeve Prve simfonije v zgodo-

${ }^{10} \mathrm{~V}$ obravnavanih glasbenih kritikah je poudarek predvsem na koncertni interpretaciji dela, ki skozi oceno le-te izkazujejo razumevanje simfonije.

${ }^{11}$ Danilo Švara [kritika], v [Slovenski poročevalec, 20. 3. 1954]. 
vini glasbe, tisti iz petdesetih let. Ta namreč govori o pravilnem slogovnem, neromantičnem in objektivnem izvajanju dela. Posamezniki v tistem času so torej kljub hipotetično manjšemu poznavanju Šostakoviča in njegovih del le razumeli Prvo simfonijo in to, kar delo interpretativno zahteva od izvajalca.

Vsa spoznanja, torej glasbena analiza Šostakovičeve Prve simfonije in analiza zapisov o njej in njenem avtorju, izkazujejo dokaj površno razumevanje skladatelja in njegovega ustvarjanja. Mnogo je izrečenih sodb, ki omenjajo posamezne "delčke" resnice, malo pa je takšnih, ki bi predstavljale bistvene elemente v skladateljevem delovanju. Mislim predvsem na dva dejavnika: razumevanje mesta Šostakoviča in njegove Prve simfonije v zgodovini glasbe ter razumevanje skladateljevega glasbeno-kompozicijsko mišljenja oziroma razumevanje estetike časa in na njej osnovane skladateljeve poetike.

Koncertni komentarji in glasbene kritike torej predstavljajo Šostakoviča kot nadaljevalca simfonične tradicije devetnajstega stoletja in tradicionalista. V njegovih delih različni avtorji opažajo različne vplive posameznih skladateljev tega obdobja. Prva simfonija je "pravzaprav tradicionalno", mladostno, sveže in celo šolsko delo. Če pa bi posamezni avtorji prej omenjena dejavnika vključevali v svoje misli, takšne interpretacije ne bi bile mogoče. In le $\mathrm{v}$ tem primeru bi bila predstava o Šostakoviču pravilna: torej predstava o skladatelju, ki ni bil tradicionalist, ki je sicer prevzemal iz tradicije, toda ob tem dodajal novo in svoje lastno glasbeno mišljenje ter na takšen način oblikoval dela nove tradicije, katere ključno delo je tudi njegova Prva simfonija. 
PRILOGA 1

\begin{tabular}{|c|c|c|c|c|}
\hline DELO & DNE & PRILOŽNOST & IZVAJALEC & KRAJ \\
\hline $\begin{array}{l}\text { Simfonija } \\
\text { št. } 9, \text { op. } 70\end{array}$ & 29.8 .1947 & $\begin{array}{l}\text { Simfonični radijski } \\
\text { koncert }\end{array}$ & $\begin{array}{l}\text { Orkester Radia Ljubljana, } \\
\text { Maribor in slovensko } \\
\text { Primorje }\end{array}$ & Mala dvorana SF \\
\hline $\begin{array}{l}\text { Simfonija } \\
\text { št. } 8, \text { op. } 65\end{array}$ & 6.11 .1947 & $\begin{array}{l}\text { Proslava ob obletnici } \\
\text { oktobrske revolucije }\end{array}$ & $\begin{array}{l}\text { Orkester Radia Ljubljana, } \\
\text { Maribor in slovensko } \\
\text { Primorje }\end{array}$ & $\begin{array}{l}\text { Velika Unionska } \\
\text { dvorana }\end{array}$ \\
\hline $\begin{array}{l}\text { Simfonija } \\
\text { št. } 8 \text {, op. } 65\end{array}$ & 10.11. 1947 & 3. simfonični koncert & $\begin{array}{l}\text { Orkester Radia Ljubljana, } \\
\text { Maribor in slovensko } \\
\text { Primorje }\end{array}$ & Velika dvorana SF \\
\hline $\begin{array}{l}\text { Simfonija } \\
\text { št. } 5, \text { op. } 47\end{array}$ & 14. 4. 1950 & $\begin{array}{l}\text { 11. simfonični } \\
\text { koncert }\end{array}$ & $\begin{array}{l}\text { Orkester Slovenske } \\
\text { filharmonije }\end{array}$ & $\begin{array}{l}\text { Velika Unionska } \\
\text { dvorana }\end{array}$ \\
\hline $\begin{array}{l}\text { Simfonija } \\
\text { št. } 6, \text { op. } 54\end{array}$ & 26. 4.1950 & Proslava OF & $\begin{array}{l}\text { Orkester Slovenske } \\
\text { filharmonije }\end{array}$ & $\begin{array}{l}\text { Velika Unionska } \\
\text { dvorana }\end{array}$ \\
\hline $\begin{array}{l}\text { Simfonija } \\
\text { št. 1, op. } 10\end{array}$ & $\begin{array}{r}23 . \text { in } \\
24.11 .1953 \\
\end{array}$ & $\begin{array}{l}\text { 2. abonmajski } \\
\text { koncert }\end{array}$ & $\begin{array}{l}\text { Orkester Slovenske } \\
\text { filharmonije }\end{array}$ & Velika dvorana SF \\
\hline $\begin{array}{l}\text { Simfonija } \\
\text { št. 1, op. } 10\end{array}$ & 16. 3. 1954 & $\begin{array}{l}\text { 7. izredni koncert ob } \\
\text { 35-letnici } \\
\text { umetniškega } \\
\text { delovanja Jakova } \\
\text { Cipcija }\end{array}$ & $\begin{array}{l}\text { Orkester Slovenske } \\
\text { filharmonije }\end{array}$ & Velika dvorana SF \\
\hline $\begin{array}{l}\text { Simfonija } \\
\text { št. 1, op. } 10\end{array}$ & $\begin{array}{r}31.1 . \text { in } \\
1.2 .1955 \\
\end{array}$ & $\begin{array}{l}\text { 3. koncert za } \\
\text { "Rumeni abonma" }\end{array}$ & $\begin{array}{l}\text { Orkester Slovenske } \\
\text { filharmonije }\end{array}$ & Velika dvorana SF \\
\hline $\begin{array}{l}\text { Simfonija } \\
\text { št. 1, op. } 10\end{array}$ & 26.5 .1955 & Simfonični koncert & $\begin{array}{l}\text { Orkester Slovenske } \\
\text { filharmonije }\end{array}$ & Sassari \\
\hline $\begin{array}{l}\text { Simfonija } \\
\text { št. 1, op. } 10 \\
\end{array}$ & 27.5 .1955 & Simfonični koncert & $\begin{array}{l}\text { Orkester Slovenske } \\
\text { filharmonije }\end{array}$ & Sassari \\
\hline $\begin{array}{l}\text { Simfonija } \\
\text { št. 1, op. } 10\end{array}$ & 30.5 .1955 & Simfonični koncert & $\begin{array}{l}\text { Orkester Slovenske } \\
\text { filharmonije }\end{array}$ & Bari \\
\hline $\begin{array}{l}\text { Simfonija } \\
\text { št. 1, op. } 10\end{array}$ & 1.6 .1955 & Simfonični koncert & $\begin{array}{l}\text { Orkester Slovenske } \\
\text { filharmonije }\end{array}$ & Brescia \\
\hline $\begin{array}{l}\text { Simfonija } \\
\text { št. 1, op. } 10\end{array}$ & 3.6 .1955 & Simfonični koncert & $\begin{array}{l}\text { Orkester Slovenske } \\
\text { filharmonije }\end{array}$ & Bologna \\
\hline $\begin{array}{l}\text { Simfonija } \\
\text { št. } 6, \text { op. } 54\end{array}$ & 15.7.1956 & Simfonični koncert & $\begin{array}{l}\text { Orkester Slovenske } \\
\text { filharmonije }\end{array}$ & $\begin{array}{l}\text { Ljubljanske } \\
\text { Križanke }\end{array}$ \\
\hline $\begin{array}{l}\text { Simfonija } \\
\text { št. } 8, \text { op. } 65 \text {, } \\
\text { odlomek }\end{array}$ & 6.11. 1957 & $\begin{array}{l}\text { Slavnostna akademija } \\
\text { ob } 40 . \text { obletnici } \\
\text { oktobrske revolucije }\end{array}$ & $\begin{array}{l}\text { Orkester Slovenske } \\
\text { filharmonije }\end{array}$ & $\begin{array}{l}\text { Velika Unionska } \\
\text { dvorana }\end{array}$ \\
\hline $\begin{array}{l}\text { Simfonija } \\
\text { št. } 5, \text { op. } 47\end{array}$ & 28. 5. 1958 & $\begin{array}{l}\text { Simfonični koncert } \\
\text { mladih umetnikov }\end{array}$ & $\begin{array}{l}\text { Orkester Slovenske } \\
\text { filharmonije }\end{array}$ & Velika dvorana SF \\
\hline $\begin{array}{l}\text { Simfonija } \\
\text { št. 1, op. } 10\end{array}$ & 9. 1. 1959 & $\begin{array}{l}\text { 3. koncert za } \\
\text { "Zeleni abonma" }\end{array}$ & $\begin{array}{l}\text { Orkester Slovenske } \\
\text { filharmonije }\end{array}$ & Velika dvorana SF \\
\hline
\end{tabular}


MUZIKOLOŠKI ZBORNIK・ MUSICOLOGICAL ANNUAL XXXVIII

PRILOGA 2

\begin{tabular}{|c|c|c|c|c|}
\hline DELO & DNE & PRULOŽNOST & IZVAJALEC & KRAJ \\
\hline $\begin{array}{l}\text { Simfonija št. } \\
11, \text { op. } 103^{12}\end{array}$ & 27. 2. 1959 & $\begin{array}{l}\text { 4. koncert za } \\
\text { "Zeleni abonma" }\end{array}$ & $\begin{array}{l}\text { Orkester Slovenske } \\
\text { filharmonije }\end{array}$ & Velika dvorana SF \\
\hline $\begin{array}{l}\text { Simfonija } \\
\text { št. 10, op. } 93\end{array}$ & 23. 11. 1959 & $\begin{array}{l}\text { 1. koncert za } \\
\text { "Rdeči abonma" }\end{array}$ & $\begin{array}{l}\text { Orkester Slovenske } \\
\text { filharmonije }\end{array}$ & Velika dvorana SF \\
\hline $\begin{array}{l}\text { Simfonija } \\
\text { št. } 6, \text { op. } 54\end{array}$ & 13. 6. 1960 & Simfonični koncert & $\begin{array}{l}\text { Orkester Slovenske } \\
\text { filharmonije }\end{array}$ & Celovec \\
\hline $\begin{array}{l}\text { Simfonija } \\
\text { št. } 5, \text { op. } 47\end{array}$ & 30. 10. 1961 & $\begin{array}{l}\text { 1. koncert za } \\
\text { "Rdeči abonma" }\end{array}$ & $\begin{array}{l}\text { Orkester Slovenske } \\
\text { filharmonije }\end{array}$ & Velika dvorana SF \\
\hline $\begin{array}{l}\text { Simfonija } \\
\text { št. } 9, \text { op. } 70^{13}\end{array}$ & 19. 3. 1962 & $\begin{array}{l}\text { 4. koncert za } \\
\text { "Rumeni abonma" }\end{array}$ & $\begin{array}{l}\text { Orkester Slovenske } \\
\text { filharmonije }\end{array}$ & Velika dvorana SF \\
\hline $\begin{array}{l}\text { Simfonija } \\
\text { št. } 1 \text {, op. } 10 \\
\end{array}$ & 5.11 .1962 & $\begin{array}{l}\text { 1. koncert za } \\
\text { "Rdeči abonma" }\end{array}$ & $\begin{array}{l}\text { Orkester Slovenske } \\
\text { filharmonije }\end{array}$ & Velika dvorana SF \\
\hline $\begin{array}{l}\text { Simfonija } \\
\text { št. 10, op. } 93 \\
\text { (1. stavek) in } \\
\text { št. } 9 \text {, op. } 70 \\
\end{array}$ & 19. 12. 1962 & $\begin{array}{l}\text { Mladinski } \\
\text { simfonični } \\
\text { koncert }\end{array}$ & $\begin{array}{l}\text { Orkester Slovenske } \\
\text { filharmonije }\end{array}$ & Velika dvorana SF \\
\hline $\begin{array}{l}\text { Simfonija } \\
\text { št. } 1, \text { op. } 10\end{array}$ & 17. 2.1964 & $\begin{array}{l}\text { 4. koncert za } \\
\text { "Rdeči abonma" }\end{array}$ & $\begin{array}{l}\text { Orkester Slovenske } \\
\text { filharmonije }\end{array}$ & Velika dvorana SF \\
\hline $\begin{array}{l}\text { Simfonija } \\
\text { št. } 6, \text { op. } 54\end{array}$ & 7.3.1966 & $\begin{array}{l}\text { 6. koncert za } \\
\text { "Zeleni abonma" }\end{array}$ & $\begin{array}{l}\text { Orkester Slovenske } \\
\text { filharmonije }\end{array}$ & Velika dvorana SF \\
\hline $\begin{array}{l}\text { Simfonija } \\
\text { št. } 6, \text { op. } 54\end{array}$ & 8. 3. 1966 & Simfonični koncert & $\begin{array}{l}\text { Orkester Slovenske } \\
\text { filharmonije }\end{array}$ & Novi Sad \\
\hline $\begin{array}{l}\text { Simfonija } \\
\text { št. } 6, \text { op. } 54 \\
\end{array}$ & 12. 3. 1966 & Simfonični koncert & $\begin{array}{l}\text { Orkester Slovenske } \\
\text { filharmonije }\end{array}$ & Budimpešta \\
\hline $\begin{array}{l}\text { Simfonija } \\
\text { št. } 6, \text { op. } 54\end{array}$ & 15.3. 1966 & Simfonični koncert & $\begin{array}{l}\text { Orkester Slovenske } \\
\text { filharmonije }\end{array}$ & Pécs \\
\hline $\begin{array}{l}\text { Koncert za } \\
\text { violino in } \\
\text { orkester } \\
\text { št. } 1, \text { op. } 99 \\
\end{array}$ & 13. 6. 1966 & $\begin{array}{l}\text { Simfonični koncert } \\
\text { z diplomanti } \\
\text { Akademije za glasbo }\end{array}$ & $\begin{array}{l}\text { Orkester Slovenske } \\
\text { filharmonije }\end{array}$ & Velika dvorana SF \\
\hline $\begin{array}{l}\text { Koncert za } \\
\text { violino in } \\
\text { orkester } \\
\text { št. 1, op. } 99 \\
\end{array}$ & 9. 1.1967 & $\begin{array}{l}\text { 2. koncert za } \\
\text { "Zeleni abonma" }\end{array}$ & $\begin{array}{l}\text { Orkester Slovenske } \\
\text { filharmonije }\end{array}$ & Velika dvorana SF \\
\hline $\begin{array}{l}\text { Koncert za } \\
\text { klavir, } \\
\text { trobento in } \\
\text { godala, } \\
\text { op. } 35 \text { in } \\
\text { Simfonija } \\
\text { št. } 6 \text {, op. } 54\end{array}$ & 16. 1.1967 & $\begin{array}{l}\text { 4. koncert za } \\
\text { "Rdeči abonma" }\end{array}$ & $\begin{array}{l}\text { Orkester Slovenske } \\
\text { filharmonije }\end{array}$ & Velika dvorana SF \\
\hline $\begin{array}{l}\text { Simfonija } \\
\text { št. } 6, \text { op. } 54\end{array}$ & 17.1 .1967 & $\begin{array}{l}\text { 3. koncert za } \\
\text { "Zeleni abonma" }\end{array}$ & $\begin{array}{l}\text { Orkester Slovenske } \\
\text { filharmonije }\end{array}$ & Velika dvorana SF \\
\hline
\end{tabular}

${ }^{12}$ Izvedena prvič v Ljubljani.

${ }^{13}$ Izvedena prvič v Ljubljani. 
PRILOGA 3

\begin{tabular}{|c|c|c|c|c|}
\hline DELO & DNE & PRILOŽNOST & IZVAJALEC & KRAJ \\
\hline $\begin{array}{l}\text { Simfonija } \\
\text { št. } 5 \text {, op. } 47\end{array}$ & 27. 3. 1967 & $\begin{array}{l}\text { 6. koncert za } \\
\text { "Rumeni abonma" }\end{array}$ & $\begin{array}{l}\text { Orkester Slovenske } \\
\text { filharmonije }\end{array}$ & Velika dvorana SF \\
\hline $\begin{array}{l}\text { Simfonija } \\
\text { št. } 5, \text { op. } 47\end{array}$ & 25. 8. 1967 & Simfonični koncert & $\begin{array}{l}\text { Orkester Slovenske } \\
\text { filharmonije }\end{array}$ & Dubrovnik \\
\hline $\begin{array}{l}\text { Simfonija } \\
\text { št. } 7, \text { op. } 60\end{array}$ & 6.11 .1967 & $\begin{array}{l}\text { Proslava ob } \\
\text { 50-letnici oktobrske } \\
\text { revolucije }\end{array}$ & $\begin{array}{l}\text { Orkester Slovenske } \\
\text { filharmonije, } \\
\text { orkester RTV ter Opere }\end{array}$ & Tivoli \\
\hline $\begin{array}{l}\text { Simfonija } \\
\text { št. } 1 \text {, op. } 10\end{array}$ & 23. 2. 1968 & $\begin{array}{l}\text { 6. koncert za } \\
\text { "Rdeči abonma" }\end{array}$ & $\begin{array}{l}\text { Orkester Slovenske } \\
\text { filharmonije }\end{array}$ & Velika dvorana SF \\
\hline $\begin{array}{l}\text { Simfonija } \\
\text { št. } 5, \text { op. } 47\end{array}$ & 15. 11. 1968 & $\begin{array}{l}\text { 3. koncert za } \\
\text { "Rdeči abonma" }\end{array}$ & $\begin{array}{l}\text { Orkester Slovenske } \\
\text { filharmonije }\end{array}$ & Velika dvorana SF \\
\hline $\begin{array}{l}\text { Koncert za } \\
\text { violončelo } \\
\text { in orkester } \\
\text { št. } 2, \text { op. } 126 \\
\end{array}$ & 22. 11. 1968 & $\begin{array}{l}\text { 1. koncert za } \\
\text { "Zeleni abonma" }\end{array}$ & $\begin{array}{l}\text { Orkester Slovenske } \\
\text { filharmonije }\end{array}$ & Velika dvorana SF \\
\hline $\begin{array}{l}\text { Simfonija } \\
\text { št. } 6, \text { op. } 54\end{array}$ & 29. 1. 1969 & Simfonični koncert & $\begin{array}{l}\text { Orkester Slovenske } \\
\text { filharmonije }\end{array}$ & Zagreb \\
\hline $\begin{array}{l}\text { Koncert za } \\
\text { violino in } \\
\text { orkester } \\
\text { st. } 2 \text {, op. } 129\end{array}$ & 13. 2. 1970 & $\begin{array}{l}\text { 6. koncert za } \\
\text { "Rumeni abonma" }\end{array}$ & $\begin{array}{l}\text { Orkester Slovenske } \\
\text { filharmonije }\end{array}$ & Velika dvorana SF \\
\hline $\begin{array}{l}\text { Simfonija } \\
\text { št. } 5, \text { op. } 47\end{array}$ & 19. 11.1971 & $\begin{array}{l}\text { 2. koncert za } \\
\text { "Rumeni abonma" }\end{array}$ & $\begin{array}{l}\text { Orkester Slovenske } \\
\text { filharmonije }\end{array}$ & Velika dvorana SF \\
\hline $\begin{array}{l}\text { Simfonija } \\
\text { št. } 5 \text {, op. } 47 \\
\end{array}$ & 21. 11. 1971 & Simfonični koncert & $\begin{array}{l}\text { Orkester Slovenske } \\
\text { filharmonije }\end{array}$ & Celovec \\
\hline $\begin{array}{l}\text { Simfonija } \\
\text { št. 10, op. } 93 \\
\end{array}$ & 16. 3. 1973 & $\begin{array}{l}\text { 3. koncert } \\
\text { "5. ciklusa" }\end{array}$ & $\begin{array}{l}\text { Orkester Slovenske } \\
\text { filharmonije }\end{array}$ & Velika dvorana SF \\
\hline $\begin{array}{l}\text { Koncert za } \\
\text { violino in } \\
\text { orkester } \\
\text { št. } 1 \text {, op. } 99 \\
\end{array}$ & 22. 2.1974 & $\begin{array}{l}\text { 1. koncert } \\
\text { "4. ciklusa" }\end{array}$ & $\begin{array}{l}\text { Orkester Slovenske } \\
\text { filharmonije }\end{array}$ & Velika dvorana SF \\
\hline $\begin{array}{l}\text { Simfonija } \\
\text { št. } 1 \text {, op. } 10\end{array}$ & 28. 2. 1974 & Simfonični koncert & $\begin{array}{l}\text { Orkester Slovenske } \\
\text { filharmonije }\end{array}$ & Koper \\
\hline $\begin{array}{l}\text { Koncert za } \\
\text { violino in } \\
\text { orkester } \\
\text { št. } 1 \text {, op. } 99\end{array}$ & 13. 12.1974 & $\begin{array}{l}\text { 2. koncert } \\
\text { "2. ciklusa" }\end{array}$ & $\begin{array}{l}\text { Orkester Slovenske } \\
\text { filharmonije }\end{array}$ & Velika dvorana SF \\
\hline $\begin{array}{l}\text { Simfonija } \\
\text { št. } 5, \text { op. } 47\end{array}$ & 21.3. 1975 & $\begin{array}{l}\text { 6. koncert } \\
\text { "6. ciklusa" }\end{array}$ & $\begin{array}{l}\text { Orkester Slovenske } \\
\text { filharmonije }\end{array}$ & Velika dvorana SF \\
\hline $\begin{array}{l}\text { Simfonija } \\
\text { št. } 5, \text { op. } 47\end{array}$ & 4.6.1976 & $\begin{array}{l}\text { 7. koncert za } \\
\text { "Oranžni abonma" }\end{array}$ & $\begin{array}{l}\text { Orkester Slovenske } \\
\text { filharmonije }\end{array}$ & Velika dvorana SF \\
\hline
\end{tabular}


MUZIKOLOŠKI ZBORNIK • MUSICOLOGICAL ANNUAL XXXVIII PRILOGA 4

\begin{tabular}{|c|c|c|c|c|}
\hline DELO & DNE & PRILOŽNOST & IZVAJALEC & KRAJ \\
\hline $\begin{array}{l}\text { Koncert za } \\
\text { klavir, } \\
\text { trobento } \\
\text { in godala, } \\
\text { op. } 35\end{array}$ & 7. 4. 1978 & $\begin{array}{l}\text { 5. koncert za } \\
\text { "Modri abonma" }\end{array}$ & $\begin{array}{l}\text { Orkester Slovenske } \\
\text { filharmonije }\end{array}$ & Velika dvorana SF \\
\hline $\begin{array}{l}\text { Simfonija } \\
\text { št. } 7 \text {, op. } 60\end{array}$ & 24. 4. 1978 & $\begin{array}{l}\text { 6. koncert za } \\
\text { "Modri abonma" }\end{array}$ & $\begin{array}{l}\text { Orkester Slovenske } \\
\text { filharmonije }\end{array}$ & Velika dvorana SF \\
\hline $\begin{array}{l}\text { Simfonija } \\
\text { št. } 7, \text { op. } 60\end{array}$ & 8. 5.1978 & Simfonični koncert & $\begin{array}{l}\text { Orkester Slovenske } \\
\text { filharmonije }\end{array}$ & Trst \\
\hline $\begin{array}{l}\text { Simfonija } \\
\text { št. } 1 \text {, op. } 10\end{array}$ & 12. 1. 1979 & $\begin{array}{l}\text { 3. koncert za } \\
\text { "Oranžni abonma" }\end{array}$ & $\begin{array}{l}\text { Orkester Slovenske } \\
\text { filharmonije }\end{array}$ & Velika dvorana SF \\
\hline $\begin{array}{l}\text { Simfonija } \\
\text { št. 14, op. } 135\end{array}$ & 23. 2. 1979 & $\begin{array}{l}\text { 4. koncert za } \\
\text { "Rumeni abonma" }\end{array}$ & $\begin{array}{l}\text { Orkester Slovenske } \\
\text { filharmonije }\end{array}$ & Velika dvorana SF \\
\hline $\begin{array}{l}\text { Simfonija } \\
\text { št. } 9, \text { op. } 70 \\
\end{array}$ & 19. 3. 1981 & Simfonični koncert & $\begin{array}{l}\text { Orkester Slovenske } \\
\text { filharmonije }\end{array}$ & Zagreb \\
\hline $\begin{array}{l}\text { Simfonija } \\
\text { št. } 9 \text {, op. } 70\end{array}$ & 20.3. 1981 & $\begin{array}{l}\text { 5. koncert za } \\
\text { "Rumeni abonma" }\end{array}$ & $\begin{array}{l}\text { Orkester Slovenske } \\
\text { filharmonije }\end{array}$ & Velika dvorana SF \\
\hline $\begin{array}{l}\text { Koncert za } \\
\text { violončelo } \\
\text { in orkester } \\
\text { št. 1, op. } 107 \\
\end{array}$ & 5.6.1981 & $\begin{array}{l}\text { 9. koncert za } \\
\text { "Rdeči abonma" }\end{array}$ & $\begin{array}{l}\text { Orkester Slovenske } \\
\text { filharmonije }\end{array}$ & Velika dvorana SF \\
\hline $\begin{array}{l}\text { Simfonija } \\
\text { št. } 6, \text { op. } 54 \\
\end{array}$ & 28. 12. 1981 & $\begin{array}{l}\text { 3. koncert za } \\
\text { "Rumeni abonma" }\end{array}$ & $\begin{array}{l}\text { Orkester Slovenske } \\
\text { filharmonije }\end{array}$ & Velika dvorana SF \\
\hline $\begin{array}{l}\text { Koncert za } \\
\text { violino in } \\
\text { orkester } \\
\text { št. 1, op. } 99 \\
\end{array}$ & 30.9. 1983 & $\begin{array}{l}\text { 1. koncert za } \\
\text { "Rdeči abonma" }\end{array}$ & $\begin{array}{l}\text { Orkester Slovenske } \\
\text { filharmonije }\end{array}$ & Cankarjev dom \\
\hline $\begin{array}{l}\text { Simfonija } \\
\text { št. } 5, \text { op. } 47\end{array}$ & 18. 11. 1983 & $\begin{array}{l}\text { 3. koncert za } \\
\text { "Rdeči abonma" }\end{array}$ & $\begin{array}{l}\text { Orkester Slovenske } \\
\text { filharmonije }\end{array}$ & Cankarjev dom \\
\hline $\begin{array}{l}\text { Simfonija } \\
\text { št. } 1 \text {, op. } 10\end{array}$ & 23. 3. 1984 & $\begin{array}{l}\text { 6. koncert za } \\
\text { "Rdeči abonma" }\end{array}$ & $\begin{array}{l}\text { Orkester Slovenske } \\
\text { filharmonije }\end{array}$ & Cankarjev dom \\
\hline $\begin{array}{l}\text { Suita za bas } \\
\text { in orkester, } \\
\text { op. } 145 a\end{array}$ & 11.5 .1984 & $\begin{array}{l}\text { 8. koncert za } \\
\text { "Rdeči abonma" }\end{array}$ & $\begin{array}{l}\text { Orkester Slovenske } \\
\text { filharmonije }\end{array}$ & Cankarjev dom \\
\hline $\begin{array}{l}\text { Simfonija } \\
\text { št. } 6, \text { op. } 54\end{array}$ & 15. 6. 1984 & $\begin{array}{l}\text { Simfonični koncert } \\
\text { mladih glasbenih } \\
\text { umetnikov }\end{array}$ & $\begin{array}{l}\text { Orkester Slovenske } \\
\text { filharmonije }\end{array}$ & Velika dvorana SF \\
\hline $\begin{array}{l}\text { Simfonija } \\
\text { št. } 5, \text { op. } 47\end{array}$ & 28. 3. 1986 & $\begin{array}{l}\text { 5. koncert za } \\
\text { "Rumeni abonma" }\end{array}$ & $\begin{array}{l}\text { Orkester Slovenske } \\
\text { filharmonije }\end{array}$ & Cankarjev dom \\
\hline $\begin{array}{l}\text { Simfonija } \\
\text { št. } 5 \text {, op. } 47\end{array}$ & 18. 5. 1986 & Simfonični koncert & $\begin{array}{l}\text { Orkester Slovenske } \\
\text { filharmonije }\end{array}$ & Evain \\
\hline $\begin{array}{l}\text { Simfonija } \\
\text { št. } 8, \text { op. } 65\end{array}$ & $\begin{array}{r}6 . \text { in } \\
7.11 .1986\end{array}$ & $\begin{array}{l}\text { 1. koncert za } \\
\text { "Modri abonma" }\end{array}$ & $\begin{array}{l}\text { Orkester Slovenske } \\
\text { filharmonije }\end{array}$ & Cankarjev dom \\
\hline
\end{tabular}


MUZIKOLOŠKI ZBORNIK • MUSICOLOGICAL ANNUAL XXXVIII

PRILOGA 5

\begin{tabular}{|c|c|c|c|c|}
\hline DELO & DNE & PRILOŽŇNOST & IZVAJALEC & KRAJ \\
\hline $\begin{array}{l}\text { Koncert za } \\
\text { klavir, trobento } \\
\text { in godala, } \\
\text { op. } 35 \\
\end{array}$ & 19. 3. 1987 & Simfonični koncert & $\begin{array}{l}\text { Orkester Slovenske } \\
\text { filharmonije }\end{array}$ & Maribor \\
\hline $\begin{array}{l}\text { Koncert } \\
\text { za klavir, } \\
\text { trobento } \\
\text { in godala, } \\
\text { op. } 35 \\
\end{array}$ & $\begin{array}{r}14 . \text { in } \\
15.5 .1987\end{array}$ & $\begin{array}{l}\text { 8. koncert za } \\
\text { "Modri abonma" }\end{array}$ & $\begin{array}{l}\text { Orkester Slovenske } \\
\text { filharmonije }\end{array}$ & Cankarjev dom \\
\hline $\begin{array}{l}\text { Simfonija, } \\
\text { št. } 5 \text {, op. } 47\end{array}$ & $\begin{array}{r}26 . \text { in } \\
27.5 .1988 \\
\end{array}$ & $\begin{array}{l}\text { 8. koncert za } \\
\text { "Modri abonma" }\end{array}$ & $\begin{array}{l}\text { Orkester Slovenske } \\
\text { filharmonije }\end{array}$ & Cankarjev dom \\
\hline $\begin{array}{l}\text { Simfonija } \\
\text { št. } 15 \text {, op. } 141\end{array}$ & $\begin{array}{r}15 . \text { in } \\
16.6 .1989 \\
\end{array}$ & $\begin{array}{l}\text { 9. koncert za } \\
\text { "Oranžni abonma" }\end{array}$ & $\begin{array}{l}\text { Orkester Slovenske } \\
\text { filharmonije }\end{array}$ & Cankarjev dom \\
\hline $\begin{array}{l}\text { Simfonija } \\
\text { št. 10, op. } 93\end{array}$ & 14.4 .1990 & Simfonični koncert & $\begin{array}{l}\text { Orkester Slovenske } \\
\text { filharmonije }\end{array}$ & Portorož \\
\hline $\begin{array}{l}\text { Simfonija } \\
\text { št. } 1, \text { op. } 10 \\
\end{array}$ & $\begin{array}{r}20 . \text { in } \\
21.12 .1990 \\
\end{array}$ & $\begin{array}{l}\text { 4. koncert za } \\
\text { "Oranžni abonma" }\end{array}$ & $\begin{array}{l}\text { Orkester Slovenske } \\
\text { filharmonije }\end{array}$ & Cankarjev dom \\
\hline $\begin{array}{l}\text { Trije plesi } \\
\text { iz } 2 . \text { Baletne } \\
\text { suite }\end{array}$ & 1. 1.1992 & Novoletni koncert & $\begin{array}{l}\text { Orkester Slovenske } \\
\text { filharmonije }\end{array}$ & Cankarjev dom \\
\hline $\begin{array}{l}\text { Simfonija } \\
\text { št. } 6, \text { op. } 54 \\
\end{array}$ & $\begin{array}{r}9 . \text { in } \\
10.1 .1992 \\
\end{array}$ & $\begin{array}{l}\text { 4. koncert za } \\
\text { "Modri abonma" }\end{array}$ & $\begin{array}{l}\text { Orkester Slovenske } \\
\text { filharmonije }\end{array}$ & Cankarjev dom \\
\hline $\begin{array}{l}\text { Koncert za } \\
\text { violino in } \\
\text { orkester } \\
\text { št. 1, op. } 99 \\
\end{array}$ & $\begin{array}{r}19 . \text { in } \\
20.10 .1992\end{array}$ & Simfonični koncert & $\begin{array}{l}\text { Orkester Slovenske } \\
\text { filharmonije }\end{array}$ & Gradec \\
\hline $\begin{array}{l}\text { Koncert za } \\
\text { violino in } \\
\text { orkester } \\
\text { št. 1, op. } 99 \\
\end{array}$ & 21. 10. 1992 & Simfonični koncert & $\begin{array}{l}\text { Orkester Slovenske } \\
\text { filharmonije }\end{array}$ & Beljak \\
\hline $\begin{array}{l}\text { Koncert za } \\
\text { violino in } \\
\text { orkester } \\
\text { št. 1, op. } 99 \\
\end{array}$ & $\begin{array}{r}22 . \text { in } \\
23.10 .1992\end{array}$ & $\begin{array}{l}\text { 2. koncert za } \\
\text { "Oranžni abonma" }\end{array}$ & $\begin{array}{l}\text { Orkester Slovenske } \\
\text { filharmonije }\end{array}$ & Cankarjev dom \\
\hline $\begin{array}{l}\text { Simfonija } \\
\text { št. } 1, \text { op. } 10 \\
\end{array}$ & 2. 12. 1992 & Simfonični koncert & $\begin{array}{l}\text { Orkester Slovenske } \\
\text { filharmonije }\end{array}$ & Velika dvorana SF \\
\hline $\begin{array}{l}\text { Simfonija } \\
\text { št. 10, op. } 93\end{array}$ & 30.11. 1994 & Simfonični koncert & $\begin{array}{l}\text { Orkester Slovenske } \\
\text { filharmonije }\end{array}$ & Celovec \\
\hline $\begin{array}{l}\text { Simfonija } \\
\text { št. } 10, \text { op. } 93 \\
\end{array}$ & $\begin{array}{r}1 . \text { in } \\
2.12 .1994 \\
\end{array}$ & $\begin{array}{l}\text { 3. koncert za } \\
\text { "Modri abonma" }\end{array}$ & $\begin{array}{l}\text { Orkester Slovenske } \\
\text { filharmonije }\end{array}$ & Cankarjev dom \\
\hline $\begin{array}{l}\text { Simfonija } \\
\text { št. 10, op. } 93\end{array}$ & 14. 12. 1994 & Simfonični koncert & $\begin{array}{l}\text { Orkester Slovenske } \\
\text { filharmonije }\end{array}$ & Salzburg \\
\hline $\begin{array}{l}\text { Simfonija } \\
\text { št. } 6, \text { op. } 54\end{array}$ & $\begin{array}{r}23 . \text { in } \\
24.3 .1995 \\
\end{array}$ & $\begin{array}{l}\text { 6. koncert za } \\
\text { "Modri abonma" }\end{array}$ & $\begin{array}{l}\text { Orkester Slovenske } \\
\text { filharmonije }\end{array}$ & Cankarjev dom \\
\hline $\begin{array}{l}\text { Simfonija } \\
\text { št. } 8, \text { op. } 65\end{array}$ & $\begin{array}{r}29.2 \text { in } \\
1.3 .1996\end{array}$ & $\begin{array}{l}\text { 5. koncert za } \\
\text { "Oranžni abonma" }\end{array}$ & $\begin{array}{l}\text { Orkester Slovenske } \\
\text { filharmonije }\end{array}$ & Cankarjev dom \\
\hline
\end{tabular}



PRILOGA 6

\begin{tabular}{|c|c|c|c|c|}
\hline DELO & DNE & PRILOŽNOST & IZVAJALEC & KRAJ \\
\hline $\begin{array}{l}\text { Simfonija } \\
\text { št. } 5 \text {, op. } 47\end{array}$ & $\begin{array}{r}13 . \mathrm{in} \\
14.6 .1996\end{array}$ & $\begin{array}{l}\text { 9. koncert za } \\
\text { "Modri abonma" }\end{array}$ & $\begin{array}{l}\text { Orkester Slovenske } \\
\text { filharmonije }\end{array}$ & Cankarjev dom \\
\hline $\begin{array}{l}\text { Koncert za } \\
\text { violino in } \\
\text { orkester } \\
\text { št. } 1 \text {, op. } 99\end{array}$ & $\begin{array}{r}26 . \mathrm{in} \\
27.9 .1996\end{array}$ & $\begin{array}{l}\text { 1. koncert za } \\
\text { "Oranžni abonma" }\end{array}$ & $\begin{array}{l}\text { Orkester Slovenske } \\
\text { filharmonije }\end{array}$ & Cankarjev dom \\
\hline $\begin{array}{l}\text { Simfonija } \\
\text { št. 10, op. } 93\end{array}$ & \begin{tabular}{|r|}
$24 . \mathrm{in}$ \\
25.10 .1996 \\
\end{tabular} & $\begin{array}{l}\text { 2. koncert za } \\
\text { "Oranžni abonma" }\end{array}$ & $\begin{array}{l}\text { Orkester Slovenske } \\
\text { filharmonije }\end{array}$ & Cankarjev dom \\
\hline $\begin{array}{l}\text { Hovanščina, } \\
\text { uvertura } \\
\text { (M. Mussorgski } \\
\text { - D. Šostakovič), } \\
\text { op. } 106\end{array}$ & $\begin{array}{r}8 . \text { in } \\
9.1 .1998 \\
\end{array}$ & $\begin{array}{l}\text { 4. koncert za } \\
\text { "Oranžni abonma" }\end{array}$ & $\begin{array}{l}\text { Orkester Slovenske } \\
\text { filharmonije }\end{array}$ & Cankarjev dom \\
\hline $\begin{array}{l}\text { Koncert za } \\
\text { klavir in } \\
\text { orkester št. } 2\end{array}$ & 29. 1. 1998 & \begin{tabular}{|l|} 
Simfonični koncert \\
v sodelovanju z \\
Akademijo za glasbo \\
\end{tabular} & $\begin{array}{l}\text { Orkester Slovenske } \\
\text { filharmonije }\end{array}$ & Velika dvorana SF \\
\hline $\begin{array}{l}\text { Simfonija } \\
\text { št. } 5 \text {, op. } 47\end{array}$ & 25.3 .1998 & Simfonični koncert & $\begin{array}{l}\text { Orkester Slovenske } \\
\text { filharmonije }\end{array}$ & Piacenza \\
\hline $\begin{array}{l}\text { Simfonija } \\
\text { št. 15, op. } 141\end{array}$ & $\begin{array}{r}16 . \text { in } \\
17.4 .1998 \\
\end{array}$ & $\begin{array}{l}\text { 7. koncert za } \\
\text { "Oranžni abonma" }\end{array}$ & $\begin{array}{l}\text { Orkester Slovenske } \\
\text { filharmonije }\end{array}$ & Cankarjev dom \\
\hline $\begin{array}{l}\text { Simfonija za } \\
\text { godala in } \\
\text { pihala, } \\
\text { op. } 73 a\end{array}$ & $\begin{array}{r}7 . \mathrm{in} \\
8.5 .1998\end{array}$ & $\begin{array}{l}\text { 8. koncert za } \\
\text { "Modri abonma" }\end{array}$ & $\begin{array}{l}\text { Orkester Slovenske } \\
\text { filharmonije }\end{array}$ & Cankarjev dom \\
\hline $\begin{array}{l}\text { Koncert za } \\
\text { violončelo in } \\
\text { orkester } \\
\text { št. 1, op. } 107\end{array}$ & $\begin{array}{r}10 . \text { in } \\
11.12 .1998\end{array}$ & $\begin{array}{l}\text { 4. koncert za } \\
\text { "Modri abonma" }\end{array}$ & $\begin{array}{l}\text { Orkester Slovenske } \\
\text { filharmonije }\end{array}$ & Cankarjev dom \\
\hline $\begin{array}{l}\text { Koncert za } \\
\text { violino in } \\
\text { orkester } \\
\text { st. 2, op. } 129 \\
\end{array}$ & 9. 6.2000 & $\begin{array}{l}\text { 8. koncert za } \\
\text { "Modri abonma" }\end{array}$ & $\begin{array}{l}\text { Orkester Slovenske } \\
\text { filharmonije }\end{array}$ & Cankarjev dom \\
\hline $\begin{array}{l}\text { Koncert za } \\
\text { violino in } \\
\text { orkester } \\
\text { št. } 1 \text {, op. } 99 \\
\end{array}$ & 14. 2. 2001 & Simfonični koncert & $\begin{array}{l}\text { Orkester Slovenske } \\
\text { filharmonije }\end{array}$ & Maribor \\
\hline $\begin{array}{l}\text { Koncert za } \\
\text { violino in } \\
\text { orkester } \\
\text { št. 1, op. } 99\end{array}$ & $\begin{array}{r}15 . \mathrm{in} \\
16.2 .2001\end{array}$ & $\begin{array}{l}\text { 5. koncert za } \\
\text { "Modri abonma" }\end{array}$ & $\begin{array}{l}\text { Orkester Slovenske } \\
\text { filharmonije }\end{array}$ & Cankarjev dom \\
\hline
\end{tabular}


PRILOGA 7

\begin{tabular}{|c|c|c|c|c|c|c|c|}
\hline & DELO & $\begin{array}{c}1947- \\
1960\end{array}$ & $\begin{array}{c}1960- \\
1970\end{array}$ & $\begin{array}{c}1970- \\
1980\end{array}$ & $\begin{array}{c}1980- \\
1990 \\
\end{array}$ & $\begin{array}{c}1990- \\
2001 \\
\end{array}$ & Skupaj \\
\hline 1 & Simfonija št. 1, op. 10 & 9 & 3 & 2 & 1 & 3 & 18 \\
\hline 2 & Simfonija št. 5, op. 47 & 2 & 4 & 4 & 4 & 2 & 16 \\
\hline 3 & Simfonija št.6, op. 54 & 2 & 7 & & 2 & 2 & 13 \\
\hline 4 & Simfonija št. 7 , op. 60 & & 1 & 2 & & & 3 \\
\hline 5 & Simfonija št. 8 , op. 65 & 2 & & & 1 & 1 & 4 \\
\hline 6 & Simfonija št. 9, op. 70 & 1 & 2 & & 1 & & 4 \\
\hline 7 & Simfonija št. 10, op. 93 & 1 & & 1 & 1 & 3 & 6 \\
\hline 8 & Simfonija št. 11, op. 103 & 1 & & & & & 1 \\
\hline 9 & $\begin{array}{l}\text { Simfonija št. } 14 \text {, za sopran, bas in } \\
\text { komorni orkester, op. } 135\end{array}$ & & & 1 & & & $\mathbf{1}$ \\
\hline 10 & Simfonija št. 15, op. 141 & & & & 1 & 1 & 2 \\
\hline 11 & Simfonija za godala in pihala, op. $73 a$ & & & & & 1 & $\mathbf{1}$ \\
\hline 12 & Koncert za klavir in orkester št. 1, op. 35 & & & . & 1 & & 1 \\
\hline 13 & Koncert za klavir in orkester št. 2 & & & & & 1 & $\mathbf{1}$ \\
\hline 14 & $\begin{array}{l}\text { Koncert za violino in } \\
\text { orkester št. } 1 \text {, op. } 99\end{array}$ & & 2 & 2 & 1 & 3 & 8 \\
\hline 15 & $\begin{array}{l}\text { Koncert za violino in } \\
\text { orkester št. } 2 \text {, op. } 129\end{array}$ & & 1 & & & 1 & 2 \\
\hline 16 & $\begin{array}{l}\text { Koncert za violončelo in } \\
\text { orkester št. 1, op. } 107\end{array}$ & & & & 1 & 1 & 2 \\
\hline 17 & $\begin{array}{l}\text { Koncert za violončelo in } \\
\text { orkester št. } 2 \text {, op. } 126\end{array}$ & & 1 & & & & $\mathbf{1}$ \\
\hline 18 & $\begin{array}{l}\text { Koncert za klavir, } \\
\text { trobento in godala, op. } 35\end{array}$ & & 1 & 1 & 1 & & 3 \\
\hline 19 & Suita za bas in orkester, op. $145 \mathrm{a}$ & & & & & 1 & 1 \\
\hline 20 & Trije plesi iz 2 . baletne suite & & & & & 1 & 1 \\
\hline 21 & $\begin{array}{l}\text { M. Mussorgski - D. Šostakovič: } \\
\text { Hovanščina, uvertura, op. } 106\end{array}$ & & & & & 1 & 1 \\
\hline
\end{tabular}




\section{PRILOGA 8}

\begin{tabular}{|c|c|c|c|c|c|c|c|}
\hline & DELO & $\begin{array}{c}1947- \\
1960 \\
\end{array}$ & $\begin{array}{c}1960- \\
1970 \\
\end{array}$ & $\begin{array}{c}1970- \\
1980 \\
\end{array}$ & $\begin{array}{c}1980- \\
1990 \\
\end{array}$ & $\begin{array}{l}1990- \\
2001\end{array}$ & Skupaj \\
\hline 1 & Simfonija št. 1 , op. 10 & 4 & 3 & 2 & 1 & 3 & 13 \\
\hline 2 & Simfonija št. 5, op. 47 & 2 & 4 & 3 & 4 & 2 & 15 \\
\hline 3 & Simfonija št. 6, op. 54 & 2 & 4 & & 2 & 2 & 10 \\
\hline 4 & Simfonija št. 7 , op. 60 & & 1 & 2 & & & 3 \\
\hline 5 & Simfonija št. 8 , op. 65 & 2 & & & 1 & 1 & 4 \\
\hline 6 & Simfonija št. 9, op. 70 & 1 & 2 & & 1 & & 4 \\
\hline 7 & Simfonija št. 10, op. 93 & 1 & & 1 & 1 & 1 & 4 \\
\hline 8 & Simfonija št. 11, op. 103 & 1 & & & & & $\mathbf{1}$ \\
\hline 9 & $\begin{array}{l}\text { Simfonija št. } 14 \text {, za sopran, bas in } \\
\text { komorni orkester, op. } 135\end{array}$ & & & 1 & & & $\mathbf{1}$ \\
\hline 10 & Simfonija št. 15 , op. 141 & & & & 1 & 1 & 2 \\
\hline 11 & Simfonija za godala in pihala, op. $73 \mathrm{a}$ & & & & & 1 & $\mathbf{1}$ \\
\hline 12 & Koncert za klavir in orkester št. 1, op. 35 & & & & 1 & & $\mathbf{1}$ \\
\hline 13 & Koncert za klavir in orkester št. 2 & & & & & 1 & 1 \\
\hline 14 & $\begin{array}{l}\text { Koncert za violino in } \\
\text { orkester št. 1, op. } 99\end{array}$ & & 2 & 2 & 1 & 1 & 6 \\
\hline 15 & $\begin{array}{l}\text { Koncert za violino in } \\
\text { orkester št. 2, op. } 129\end{array}$ & & 1 & & & 1 & 2 \\
\hline 16 & $\begin{array}{l}\text { Koncert za violončelo in } \\
\text { orkester št. 1, op. } 107\end{array}$ & & & & 1 & 1 & 2 \\
\hline 17 & $\begin{array}{l}\text { Koncert za violončelo in } \\
\text { orkester št. } 2 \text {, op. } 126\end{array}$ & & 1 & & & & $\mathbf{1}$ \\
\hline 18 & $\begin{array}{l}\text { Koncert za klavir, trobento in } \\
\text { godala, op. } 35\end{array}$ & & 1 & 1 & 1 & & 3 \\
\hline 19 & Suita za bas in orkester, op. $145 \mathrm{a}$ & & & & & 1 & $\mathbf{1}$ \\
\hline 20 & Trije plesi iz 2 . baletne suite & & & & & 1 & 1 \\
\hline 21 & $\begin{array}{l}\text { M. Mussorgski - D. Šostakovič: } \\
\text { Hovanščina, uvertura, op. } 106\end{array}$ & & & & & 1 & $\mathbf{1}$ \\
\hline
\end{tabular}

